\section{Autoantibody to PL-12 (Anti-Alanyl-tRNA Synthetase) in an African American Girl with Juvenile Dermatomyositis and Resolution of Interstitial Lung Disease}

To the Editor:

Juvenile dermatomyositis (JDM) is an immune-mediated pediatric idiopathic inflammatory myopathy (IIM) characterized by muscle and skin inflammation ${ }^{1}$. Anti-PL-12 is a myositis-specific antibody (MSA), directed against alanine-tRNA synthetase $\mathrm{e}^{2}$, often with debilitating interstitial lung disease (ILD), that is sporadically reported in childhood ${ }^{3}$. We describe a child with anti-PL-12 antibody who recovered lung function after therapy.

A 14-year-old African American girl developed bilateral ankle stiffness associated with swelling and redness of the upper eyelid. One month later, she noticed proximal weakness of shoulder girdle and pelvic girdle. Four months later, she had fever to $102^{\circ} \mathrm{F}$; an erythematous rash over upper chest, arms, and upper eyelids; difficulty walking and getting up from bed, with shortness of breath during exertion. After admission to intensive care unit for suspected aspiration pneumonia, she was diagnosed with JDM on the basis of a muscle biopsy. She received intravenous (IV) steroid (30 $\mathrm{mg} / \mathrm{kg} / \mathrm{dose}$ ) for 5 days, followed by oral prednisone ( $1 \mathrm{mg} / \mathrm{kg} / \mathrm{day})$, and was lost to followup.

Six months later, she was admitted to Children's Memorial Hospital with fever, malaise, weakness, worsening rash, and bilateral knee arthritis. Laboratory data were elevated: creatine kinase 12,464 IU/l (normal 29-165 $\mathrm{IU} / 1$ ), aldolase $150 \mathrm{U} / 1$ (normal 3.4-8.6 U/l), alanine transaminase $156 \mathrm{IU} / 1$ (normal 2-30 IU/1), aspartate transaminase 257 IU/1 (normal 16-52 IU/1), and lactate dehydrogenase 1496 IU/1 (normal 126-289 IU/l). Markers of inflammation were increased: erythrocyte sedimentation rate (ESR) 37 $\mathrm{mm} / \mathrm{h}$ (normal $<20 \mathrm{~mm} / \mathrm{h}$ ), C-reactive protein (CRP) $4.41 \mathrm{mg} / \mathrm{dl}$ (normal $<0.8 \mathrm{mg} / \mathrm{dl}$ ), von Willebrand factor antigen (vWF:Ag) $420 \%$ (blood group B normal $=57 \%-241 \%$ ); and elevated neopterin level $30.4 \mathrm{~nm} / 1$ (normal < $10 \mathrm{~nm} / \mathrm{l}$ ). Periungual capillaroscopy showed dilated capillaries, and moderately severe dropout of the nailfold capillary end-row loop (ERL): 4.28 (normal value $7-10)^{4}$.

Tests for anti-dsDNA, Scl-70, and rheumatoid factor were negative, but her sera were positive for anti-Ro and anti-PL-12 (laboratory of Dr. I. Targoff ${ }^{5}$ ). On pulmonary function testing, she had decreased forced vital capacity, $73 \%$, and diffusion capacity (DLCO/VA) of 66\%, consistent with restrictive lung disease (Table 1). Computed tomography (CT) scan of the chest showed peripheral intralobular and interlobular septal thickening, early parenchymal cystic changes, and micronodules consistent with ILD (Figure 1). Dual energy X-ray absorptiometry scan showed a lumbar Z score of -1.9 (consistent with osteopenia) and vitamin $\mathrm{D}$ deficiency (25-hydroxy D total $25.2 \mathrm{ng} / \mathrm{ml}$; normal 30-119 ng/ml]. Over the next 17 months, she developed persistent osteopenia (lumbar Z score of -2.6), despite supplementation with calcium and vitamin $\mathrm{D}$ and attaining a therapeutic level of vitamin D.

Therapy included $1 \mathrm{~g}$ IV methylprednisolone (IVMP), on 3 consecutive days, followed by twice weekly for the first 3 months; oral prednisolone 20 $\mathrm{mg} /$ day $(0.43 \mathrm{mg} / \mathrm{kg})$ on non-pulse days; methotrexate IV followed by subcutaneous (SC; $15 \mathrm{mg} / \mathrm{m}^{2}$ ) weekly and monthly IV cyclophosphamide (500 $\mathrm{mg} / \mathrm{m}^{2}$ ) for 6 months. One month after completion of cyclophosphamide she had a normal leukocyte count, and she was given mycophenolate mofetil (MMF) $1000 \mathrm{mg}$ daily $(21 \mathrm{mg} / \mathrm{kg} /$ day) and continued with IVMP pulses every other week for 8 months and SC methotrexate weekly. IV administration of methylprednisolone was utilized because of prolonged active vasculitis characterized by a persistent rash associated with microvascular damage reflected by loss of nailfold capillary ERL, as well as positive indicators of immune activation and endothelial cell damage (elevated levels of vWF:Ag, low C4, decreased CD3-negative natural killer cells $)^{6}$. Rouster-Stevens, et al showed that patients with JDM and ERL loss may have decreased bioavailability of oral prednisone compared with IVMP $^{7}$. IVMP was tapered only after symptoms and all laboratory data were normal, including muscle enzymes and other markers of inflammation (ESR, CRP, and vWF:Ag), following the authors' treatment protocol for severe $\mathrm{JDM}^{8}$. Two years after starting therapy at Children's Memorial Hospital, she takes prednisone $5 \mathrm{mg}$ daily $(0.1 \mathrm{mg} / \mathrm{kg} / \mathrm{day})$; SC methotrexate $15 \mathrm{mg} / \mathrm{m}^{2}$ every week; MMF $2500 \mathrm{mg}$ daily ( $40 \mathrm{mg} / \mathrm{kg} /$ daily); folic acid $1 \mathrm{mg}$; calcium $1600 \mathrm{mg}$; and vitamin D 50,000 units/month. The pulmonary function essentially normalized after 5 months of therapy and the serologic indices of inflammation normalized after 17 months. Her CT scan showed resolution of interstitial and interlobular septal thickening with minimal residual micronodules (Figure 1).

The most common myositis-specific antibodies are directed against aminoacyl-tRNA synthetase, one of the enzymes catalyzing the attachment of a particular amino acid to its transfer RNA ${ }^{2}$. Patients with aminoacyltRNA synthetase have the anti-synthetase syndrome: myositis, polyarthritis, fever, Raynaud's phenomenon, ILD, and mechanic's hands 9 . In a study of 77 children, $12(16 \%)$ had myositis-specific antibodies and one had antiPL- $12^{3}$. Myositis-specific antibodies are found in 16\%-26\% of adults with $\mathrm{IIM}^{2}$; anti-PL-12 is present in $<5 \%$. Anti-PL-12 is highly associated with $\mathrm{ILD}^{5}$; in 31 adults, ILD was present in $90 \%$, and preceded the diagnosis of connective tissue disease in $53 \%{ }^{10}$.

Our patient's pulmonary function tests showed a pattern of restrictive lung disease, commonly associated with diminished core strength as well as a diffusion defect ${ }^{11}$. The chest CT identified interlobular septal thickening, one of the most common radiological findings in PL-12-positive adults. Although myositis is usually mild in patients with anti-PL- $12^{5,10}$, our patient had severe myositis with markedly elevated muscle enzymes, and her score on the Childhood Myositis Assessment Scale ${ }^{12}$ was markedly decreased at 21/52. She was negative for antibody to ribonuclear protein, which is present in $36 \%-65 \%$ of patients who are anti-PL-12-positive ${ }^{10}$. VWF:Ag is often an indicator of a disease flare in $\mathrm{IIM}^{13,14}$, and our patient exhibited high vWF:Ag levels at presentation, persisting for 9 months. Her disease course was similar to those of adults with both anti-PL-12 and anti-Ro antibody, in whom ILD is difficult to control. In contrast to reported cases, however, her pulmonary function tests normalized and the chest CT scan showed significant resolution of ILD. To our knowledge this is the first complete report of a child with IIM with both anti-PL-12 and anti-Ro autoantibodies and improvement of lung function in response to intensive immunosuppressive therapy.

Table 1. Lung function data over time (dates shown). All data are percentages.

\begin{tabular}{lccccc}
\hline & Pretreatment & \multicolumn{5}{c}{ Posttreatment } \\
& $6 / 16 / 2008$ & $11 / 19 / 2008$ & $2 / 4 / 2009$ & $5 / 27 / 2009$ & $11 / 11 / 2009$ \\
\hline FEV1 & 73 & 94 & 91 & 98 & 100 \\
FVC & 70 & 99 & 96 & 96 & 95 \\
FEV1/FVC & 89 & 88 & 108 & 100 & 96 \\
TLC & 79 & 90 & 93 & 88 & 87 \\
DLCOc/VA & 66 & 88 & 96 & 91 & 86 \\
\hline
\end{tabular}

FEV: forced expiratory volume; FVC: forced vital capacity; TLC: total lung capacity. 

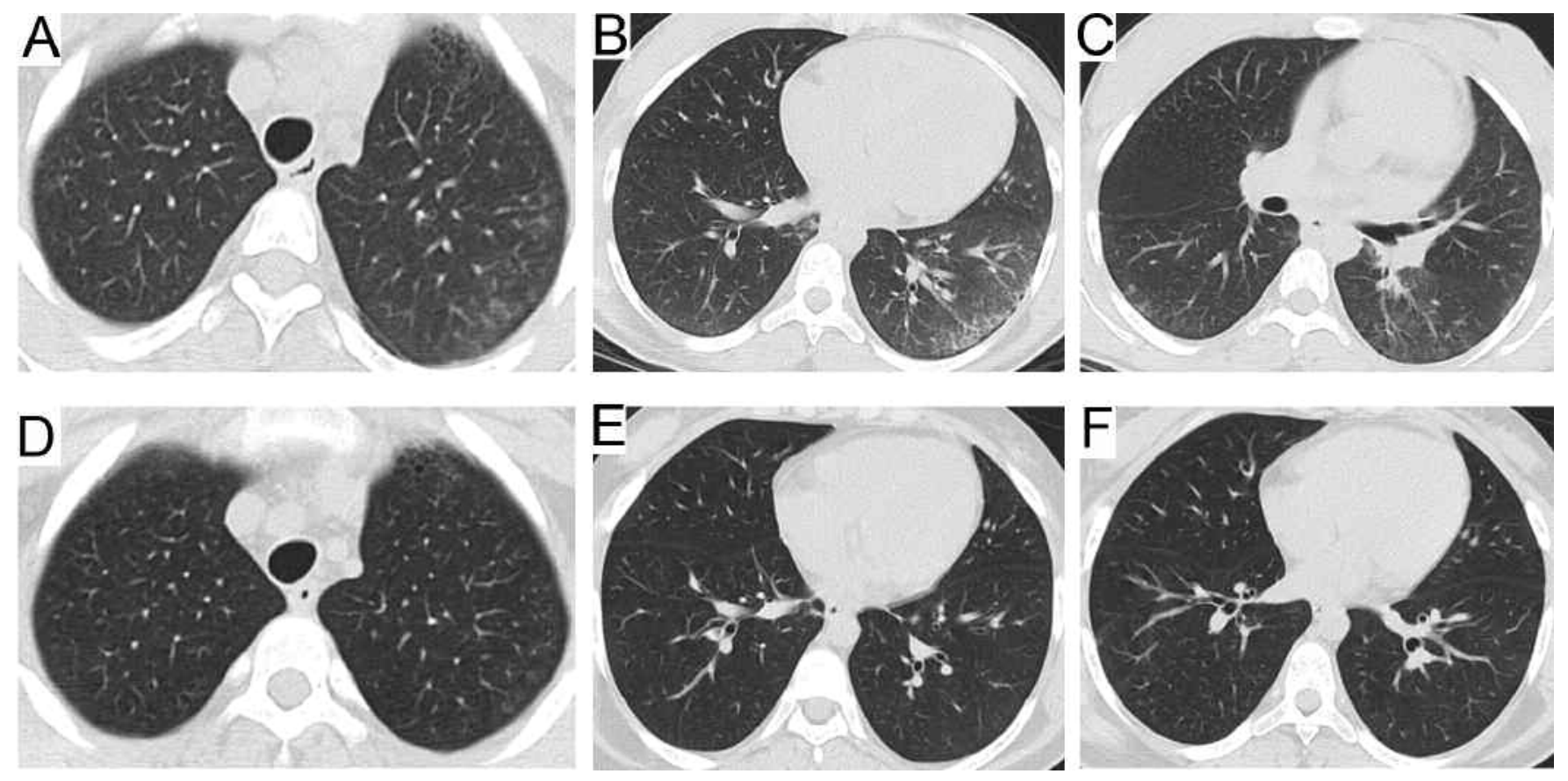

Figure 1. CT scans before treatment showing peripheral intralobular interstitial thickening at the lung bases, left greater than right (A, B, C); and after treatment showing resolution of previous changes (D, E, F).

PATRICIA VEGA, MD, Department of Pediatrics, University of Texas Health Science Center, San Antonio, Texas; MARIA IBARRA, MD, Division of Rheumatology, Children's Memorial Hospital, Department of Pediatrics, Northwestern University Feinberg School of Medicine, Chicago, Illinois; ADRIENNE PRESTRIDGE, MD, Department of Pediatrics, Northwestern University Feinberg School of Medicine, Division of Pulmonology, Children's Memorial Hospital, Chicago, Illinois; LAUREN M. PACHMAN, MD, Division of Rheumatology, Children's Memorial Hospital, Department of Pediatrics, Northwestern University Feinberg School of Medicine, Department of Clinical Immunology, Children's Memorial Research Center, Chicago, Illinois, USA. Address correspondence to Dr. L.M. Pachman, Children's Memorial Research Center, 2300 Children's Plaza, Box 212, Chicago, IL 60614. E-mail: pachman@northwestern.edu

Supported by NIH/NIAMS R01 AR48289, the Cure JM Foundation, and the Macy's Miracle Foundation.

\section{REFERENCES}

1. Feldman BM, Rider LG, Reed AM, Pachman LM. Juvenile dermatomyositis and other idiopathic inflammatory myopathies of childhood. Lancet 2008;371:2201-12.

2. Hengstman GJ, van Engelen BG, Vree Egberts WT, van Venrooij WJ. Myositis-specific autoantibodies: Overview and recent developments. Curr Opin Rheumatol 2001;13:476-82.

3. Rider LG, Miller FW, Targoff IN, Sherry DD, Samayoa E, Lindahl $\mathrm{M}$, et al. A broadened spectrum of juvenile myositis-specific autoantibodies in children. Arthritis Rheum 1994;37:1534-8.

4. Christen-Zaechs S, Seshadri R. Sundberg J, Paller AS, Pachman LM. Juvenile dermatomyositis: Persistent association of nailfold capillaroscopy changes and skin involvement over 36 months with duration of untreated disease. Arthritis Rheum 2008;58:571-6.

5. Targoff IN, Arnett FC. Clinical manifestations in patients with antibody to PL-12 antigen (alanyl-tRNA synthetase). Am J Med 1990;88:241-51.

6. Pachman LM, Geraci N, Morgan G, Daniels B, Seshadri R, Sullivan D, et al. Absolute number of circulating
CD3-CD56+/CD16+ natural killer (NK) cells, a potential biomarker of disease activity in juvenile dermatomyositis (JDM) [abstract]. Arthritis Rheum 2008;58 Suppl:S225.

7. Rouster-Stevens KA, Gursahaney A, Ngai K-L, Daru JA, Pachman LM. Pharmacokinetic study of oral prednisolone compared with intravenous methylprednisolone in patients with juvenile dermatomyositis. Arthritis Care Res 2008;59:222-66.

8. Rouster-Stevens KA, Morgan GA, Wang D, Pachman LM. Mycophenolate mofetil, a possible therapeutic agent for children with juvenile dermatomyositis. Arthritis Care Res 2010;62:1446-51

9. Love LA, Leff RL, Fraser DD, Targoff IN, Dalakas M, Plotz PH, et al. A new approach to the classification of idiopathic inflammatory myopathy: Myositis-specific autoantibodies define useful homogeneous patient groups. Medicine (Baltimore) 1991;70:360-74.

10. Kalluri M, Sahn SA, Oddis CV, Gharib SL, Christopher-Stine L, Danoff SK, et al. Clinical profile of anti-PL-12 autoantibody: Cohort study and review of the literature. Chest 2009;135:1550-6.

11. Pachman LM, Cooke N. Juvenile dermatomyositis: A clinical and immunological study. J Pediatr 1980;96:226-34.

12. Huber AM, Feldman BM, Rennebohm RM, Hicks JE, Lindsley CB, Perez MD, et al. Juvenile Dermatomyositis Disease Activity Collaborative Study Group. Validation and clinical significance of the Childhood Myositis Assessment Scale for assessment of muscle function in the juvenile idiopathic inflammatory myopathies. Arthritis Rheum 2004;50:1595-603.

13. Guzman J, Petty RE, Malleson PN. Monitoring disease activity in juvenile dermatomyositis: The role of von Willebrand factor and muscle enzymes. J Rheumatol 1994;21:739-43.

14. Ansell BA, Miller JJ III, Pachman LM, Sullivan DB. Controversies in juvenile dermatomyositis. J Rheumatol 1990;17:1-6.

J Rheumatol 2011;38:2; doi:10.3899/jrheum.100608 Personal non-commercial use only. The Journal of Rheumatology Copyright @ ${ }^{2011 . ~ A l l ~ r i g h t s ~ r e s e r v e d . ~}$ 